\title{
Observations of floating anthropogenic litter in the Barents Sea and Fram Strait, Arctic
}

\author{
Melanie Bergmann ${ }^{1} \cdot$ Nadja Sandhop $^{1} \cdot$ Ingo Schewe $^{1} \cdot$ Diederik D'Hert $^{2}$
}

Received: 25 May 2015/Revised: 30 September 2015/Accepted: 6 October 2015/Published online: 21 October 2015

(C) The Author(s) 2015. This article is published with open access at Springerlink.com

\begin{abstract}
Although recent reports indicate that anthropogenic waste has made it to the remotest parts of our oceans, there is still only limited information about its spread, especially in polar seas. Here, we present litter densities recorded during ship- and helicopter-based observer surveys in the Barents Sea and Fram Strait (Arctic). Thirty-one items were recorded in total, 23 from helicopter and eight from research vessel transects. Litter quantities ranged between 0 and 0.216 items $\mathrm{km}^{-1}$ with a mean of $0.001( \pm$ SEM 0.005$)$ items km ${ }^{-1}$. All of the floating objects observed were plastic items. Litter densities were slightly higher in the Fram Strait $\left(0.006\right.$ items km $\left.{ }^{-1}\right)$ compared with the Barents Sea $\left(0.004\right.$ items $\left.\mathrm{km}^{-1}\right)$. More litter was recorded during helicopter-based surveys than during ship-based surveys (0.006 and 0.004 items $\mathrm{km}^{-1}$, respectively). When comparing with the few available data with the same unit (items $\mathrm{km}^{-1}$ transect), the densities found herein are slightly higher than those from Antarctica but substantially lower than those from temperate waters. However, since anthropogenic activities in the Fram Strait are expanding because of sea ice shrinkage, and since currents from the North Atlantic carry a continuous supply of litter to the north, this problem is likely to worsen in years to come unless serious mitigating actions are taken to reduce the amounts of litter entering the oceans.
\end{abstract}

Melanie Bergmann

Melanie.Bergmann@awi.de

1 HGF-MPG Group for Deep-Sea Ecology and Technology, Alfred-Wegener-Institut, Helmholtz-Zentrum für Polar- und Meeresforschung, Am Handelshafen 12,

27570 Bremerhaven, Germany

2 Laboratory for Polar Ecology (PolE), Rue du Fodia, 18, 1367 Ramillies, Belgium
Keywords Litter - Marine debris - Plastic pollution · Arctic $\cdot$ Barents Sea $\cdot$ Observer survey

\section{Introduction}

Objects floating at the sea surface have been reported from locations all over the world (e.g. Eriksen et al. 2014; Galgani et al. 2015). Such objects can be of both natural and anthropogenic origin. Natural floatsam comprises seaweeds, wood, other plant debris, animal carcasses and volcanic pumice (Kiessling et al. 2015). Floating anthropogenic litter was first brought to our attention in the early 1960s when recovered from the alimentary tract of seabirds (Ryan 2015). Such objects comprise timber, tar lumps and to a great extent plastic (Kiessling et al. 2015).

Although the disposal of solid waste at sea was already prohibited under the MARPOL Convention (Annex V) in 1988, increasing numbers of reports indicate that the problem continues to be widespread (Galgani et al. 2015) highlighting the importance of land-based litter entering the oceans. Even the remotest environments such as polar regions and the deep ocean floor are no longer free of litter (Barnes 2002; Galgani et al. 2015). Plastic accounts for the great majority of marine litter (Cózar et al. 2014), which is not surprising given an annual global production of 299 million tons (status 2013, PlasticsEurope 2015). Recently, it has been estimated that 275 million tons of plastic waste were generated in 192 coastal countries in 2010, of which up to 12.7 million $\mathrm{t}$ entered the ocean (Jambeck et al. 2015). However, Eriksen et al. (2014) reported 'only' $250,000 \mathrm{t}$ of litter floating in the oceans worldwide. This discrepancy of several orders of magnitude indicates the presence of hitherto unidentified sinks of marine litter. 
Floating litter interacts with marine life in various ways. Most obviously, it causes entanglement and suffocation and interferes with food uptake and digestion of 580 marine species (Kühn et al. 2015). Plastics are long lasting and non-biodegradable (Andrady 2015) and carry added and/or adsorbed pollutants (Engler 2012). If ingested, these may accumulate through the food web (Kühn et al. 2015). Entanglement in or attachment to floating litter opens new routes of biota transportation, which could enable alien invasion (Kiessling et al. 2015). Long-distance transport may be enhanced by storms/strong winds (Kukulka et al. 2012). The risk of alien invasion may pose a particular threat to polar regions (Barnes 2002) such as the Arctic, which is currently one of the fastest warming areas of our planet. The resulting decrease in sea ice, which previously might have acted as a barrier to marine litter inputs and which has already led to increased shipping traffic in the area (Bergmann and Klages 2012), may result in greater litter inputs to the Arctic Ocean. Van Sebille et al. (2012) projected the presence/formation of a sixth garbage patch in the Barents Sea region, which may leak into the Fram Strait. Despite these implications, only limited information is currently available on the distribution of floating litter in polar regions (Barnes 2002; Prokhorova 2014). To address this issue, we report sightings of litter floating at the sea surface of the Barents Sea and Fram Strait recorded from a helicopter and a research vessel.

\section{Materials and methods}

\section{Study area}

In 1999, the Alfred Wegener Institute, Helmholtz Centre for Polar and Marine Research, established the HAUSGARTEN observatory (Bergmann and Klages 2012) in the eastern Fram Strait (Arctic), which was the focus of the current expedition. The Fram Strait is the only deep-water connection for exchange of deep and intermediate water masses between the North Atlantic and the Arctic Ocean. The hydrography is characterised by the inflow of warm Atlantic water from the Nordic Seas into the central Arctic Ocean. At $78^{\circ}-80^{\circ} \mathrm{N}$, part of the northward flowing Atlantic water (West Spitsbergen Current) is re-circulated within the Return Atlantic Current (Beszczynska-Möller et al. 2012) (Fig. 1). Here, the remaining Atlantic water divides into the Svalbard Branch, following the perimeter of the Svalbard Islands, and the Yermak Branch, flowing along the western and northern flanks of the Yermak Plateau. Cooler less saline polar waters from the central Arctic Ocean flow along the western Fram Strait (East Greenland
Current). The eastern and western currents are separated by the East Greenland Polar Front. As a result, the sea ice cover is variable, with permanently ice-covered areas in western parts, permanently ice-free areas in southeastern parts and seasonally varying ice conditions in the central and northeast Fram Strait.

\section{Counts of floating litter}

Litter items floating at the sea surface were recorded as part of a long-term study on the distribution of seabirds and marine mammals in polar seas (Joiris 2000) during $R V$ Polarstern expedition ARK XXVII/2 in July 2012. They were recorded during $30-\mathrm{min}$ transect counts from the bridge while sailing at a mean speed ranging from 4.7 to 12.7 knots. Observations were done up to a $90^{\circ}$ angle on either starboard or portside of the bridge ( $18 \mathrm{~m}$ above sea level) depending on the light conditions and visibility without width limitation [see Joiris (2000) for more details]. Objects were detected by eye and suspicions confirmed with high-quality binoculars (Swarovski and Kite, $10 \times 42$ and $10 \times 50$ ) or telescopes (Swarovski or Zeiss, 25-50x-80). The position of floating litter was taken from the ship's data acquisition system. The minimum size of detected floating objects was $20 \mathrm{~cm}$.

In addition, helicopter flights were undertaken to increase the geographic range and to allow comparison between data obtained from the two different observation platforms. Helicopters of the model MBB BO-105 CBS (HeliService International $\mathrm{GmbH}$, Germany) were used at a mean flight altitude between 53 and $249 \mathrm{~m}$ (Table 1) and a mean speed ranging from 109 to $182 \mathrm{~km} \mathrm{~h}^{-1}$. Litter was recorded by the pilot and two observers using a hand-held Garmin GPS for navigational data acquisition.

Unfortunately, no calibration had been done to estimate the transect widths prior to helicopter flights and ship surveys as this had not been a part of the mammal/bird survey protocol used. Therefore, we were unable to calculate litter densities per area and rather converted counts to linear density (items per $\mathrm{km}$ distance). To this end, the survey distances were calculated from the ship's and helicopter's position acquisition systems, which enabled conversion of litter counts to linear density (item $\mathrm{km}^{-1}$ ).

Data analysis was done using the software Minitab 14. In addition, the course track and positions of each transect and of each litter observation were plotted in a geographic information system (ESRI ArcGIS 10.0) via ArcMap 10.0. The base map layer 'Lighting Gray Canvas' and Mercator and stereographic North Pole projection (WGS 1984 Web Mercator Auxiliary Sphere, WGS 1984 IBCAO Polar Stereographic) were used. 
Fig. 1 Map of transect tracks of $R V$ Polarstern and helicopters and of plastic litter floating at the sea surface recorded by observers. Arrows highlight the prevailing water currents in the region. $S B$ Svalbard Branch, $Y B$ Yermak Branch (adapted from Beszczynska-Möller et al. 2012)

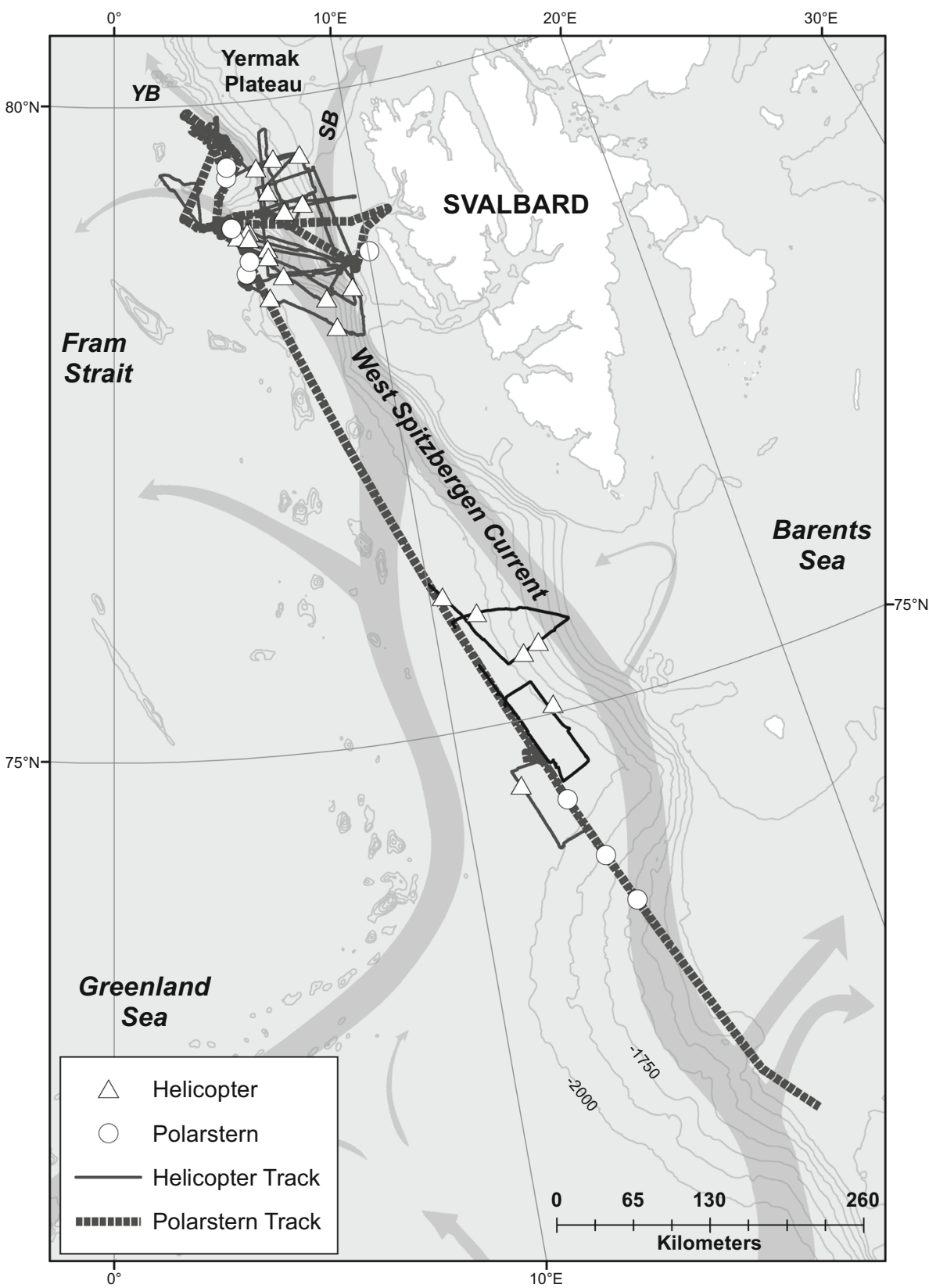

A total distance of $2031.0 \mathrm{~km}$ was covered in 31 shipbased surveys (Table 1). Eight floating plastic litter items were seen in total during six of these (19\%), and quantities ranged from 0 to 0.21570 items $\mathrm{km}^{-1}$. Although the majority of floating litter was observed on the westernmost flanks of the area surveyed (eastern Fram Strait, west of Svalbard), three items were also recorded from the Barents Sea during $R V$ Polarstern's transit to Troms $\varnothing$ (Fig. 1). Less litter was observed closer to the coast of Svalbard. Ice was only seen during the four northernmost transects, where no flotsam was recorded. Litter density was significantly correlated with ship speed (Pearson correlation, $r=-0.45$, $p=0.012$ ). 
Table 1 Litter quantities recorded during observer surveys made from $R V$ Polarstern (S) or a helicopter (H) during expedition ARK XXVII-2

\begin{tabular}{|c|c|c|c|c|c|c|c|c|c|c|}
\hline Date & $\begin{array}{l}\text { Time } \\
\text { (h) }\end{array}$ & Platform & Latitude & Longitude & $\begin{array}{l}\text { Mean altitude } \\
\text { (m) }\end{array}$ & Ice & $\begin{array}{l}\text { Distance } \\
(\mathrm{km})\end{array}$ & $\begin{array}{l}\text { Litter } \\
\text { count }\end{array}$ & $\begin{array}{l}\text { Litter count } \\
\mathrm{km}^{-1}\end{array}$ & Litter type \\
\hline \multirow[t]{2}{*}{$17 / 07 / 2012$} & $13: 39$ & $\mathrm{H}$ & 79.133 & 6.1529 & 170 & - & 297.9 & 0 & 0 & \\
\hline & $15: 18$ & & 79.135 & 6.1041 & 1 & & & & & \\
\hline \multirow[t]{2}{*}{$18 / 07 / 2012$} & $13: 56$ & $\mathrm{H}$ & 78.619 & 9.3898 & 158 & - & 316.5 & 0 & 0 & \\
\hline & $15: 55$ & & 78.691 & 9.4107 & 3 & & & & & \\
\hline \multirow[t]{2}{*}{$19 / 07 / 2012$} & $14: 05$ & $\mathrm{H}$ & 78.934 & 4.9901 & 196 & - & 254.9 & 4 & 0.01569 & Plastic waste \\
\hline & $15: 35$ & & 78.9 & 5.0769 & 2 & & & & & \\
\hline \multirow[t]{2}{*}{$20 / 07 / 2012$} & $09: 38$ & $\mathrm{H}$ & 78.611 & 5.0828 & 219 & - & 299.8 & 3 & 0.01001 & Plastic waste \\
\hline & $11: 32$ & & 78.611 & 5.0644 & 5 & & & & & \\
\hline \multirow[t]{2}{*}{$22 / 07 / 2012$} & $09: 27$ & $\mathrm{H}$ & 79.06 & 3.4741 & 53 & - & 136.0 & 0 & 0 & \\
\hline & $10: 34$ & & 79.06 & 3.4731 & 1 & & & & & \\
\hline \multirow[t]{2}{*}{$23 / 07 / 2012$} & $13: 33$ & $\mathrm{H}$ & 79.736 & 4.4943 & 70 & - & 82.1 & 0 & 0 & \\
\hline & $14: 42$ & & 79.729 & 4.4581 & 1 & & & & & \\
\hline \multirow[t]{2}{*}{$26 / 07 / 2012$} & $15: 54$ & $\mathrm{H}$ & 79.564 & 5.2680 & 141 & - & 405.1 & 6 & 0.01481 & $\begin{array}{l}5 \times \text { Plastic } \\
\text { waste }\end{array}$ \\
\hline & $18: 22$ & & 79.406 & 4.7528 & 1 & & & & & 1 Plastic bag \\
\hline \multirow[t]{2}{*}{$27 / 07 / 2012$} & $10: 33$ & $\mathrm{H}$ & 79.1 & 4.4687 & 180 & - & 264.5 & 0 & 0 & \\
\hline & $12: 20$ & & 79.1 & 4.5487 & 3 & & & & & \\
\hline \multirow[t]{2}{*}{$27 / 07 / 2012$} & $14: 38$ & $\mathrm{H}$ & 78.98 & 4.8535 & 249 & - & 257.6 & 4 & 0.01553 & Plastic waste \\
\hline & $16: 41$ & & 78.921 & 5.0526 & 3 & & & & & (wood) \\
\hline \multirow[t]{2}{*}{$27 / 07 / 2012$} & $16: 40$ & $\mathrm{H}$ & 78.921 & 5.0519 & 193 & - & 266.0 & 0 & 0 & \\
\hline & $18: 46$ & & 78.638 & 5.5656 & 3 & & & & & \\
\hline \multirow[t]{2}{*}{$28 / 07 / 2012$} & $08: 31$ & $\mathrm{H}$ & 76.148 & 10.0481 & 205 & - & 270.7 & 5 & 0.01847 & $\begin{array}{c}4 \times \text { Plastic } \\
\text { waste }\end{array}$ \\
\hline & $10: 37$ & & 75.794 & 10.6190 & 2 & & & & & 1 Rope \\
\hline \multirow[t]{2}{*}{$28 / 07 / 2012$} & $12: 22$ & $\mathrm{H}$ & 75.471 & 11.1291 & 202 & - & 287.3 & 0 & 0 & \\
\hline & $14: 18$ & & 75.128 & 11.6528 & 4 & & & & & \\
\hline \multirow[t]{2}{*}{$28 / 07 / 2012$} & $15: 08$ & $\mathrm{H}$ & 74.991 & 11.8655 & 211 & - & 398.9 & 1 & 0.00251 & Plastic waste \\
\hline & $17: 03$ & & 74.673 & 12.3361 & 2 & & & & & \\
\hline $\begin{array}{l}\text { Total } \\
\text { helicopter }\end{array}$ & & & & & & & 3537.5 & 23 & 0.00650 & \\
\hline $15 / 07 / 2012$ & $17: 50$ & $\mathrm{~S}$ & 78.1539 & 13.6005 & & - & 224.9 & 1 & 0.00445 & Plastic bag \\
\hline $16 / 07 / 2012$ & $03: 20$ & & 78.9740 & 4.6232 & & & & & & \\
\hline \multirow[t]{2}{*}{$16 / 07 / 2012$} & $12: 20$ & $\mathrm{~S}$ & 79.0794 & 4.1209 & & - & 8.9 & 0 & 0 & \\
\hline & $12: 50$ & & 79.0430 & 4.4781 & & & & & & \\
\hline \multirow[t]{2}{*}{$16 / 07 / 2012$} & $22: 30$ & $\mathrm{~S}$ & 79.0693 & 4.1808 & & - & 9.1 & 0 & 0 & \\
\hline & 23:00 & & 79.0990 & 4.5847 & & & & & & \\
\hline \multirow[t]{2}{*}{$17 / 07 / 2012$} & 02:05 & $\mathrm{S}$ & 79.1107 & 4.5980 & & - & 7.4 & 0 & 0 & \\
\hline & $02: 35$ & & 79.1299 & 4.9018 & & & & & & \\
\hline \multirow[t]{2}{*}{$17 / 07 / 2012$} & $06: 00$ & $\mathrm{~S}$ & 79.1326 & 4.9900 & & - & 26.4 & 0 & 0 & \\
\hline & $07: 30$ & & 79.1317 & 6.2515 & & - & & & & \\
\hline \multirow[t]{2}{*}{$17 / 07 / 2012$} & $17: 00$ & $\mathrm{~S}$ & 79.1353 & 6.1000 & & - & 6.0 & 0 & 0 & \\
\hline & $17: 30$ & & 79.1154 & 6.0772 & & & & & & \\
\hline $17 / 07 / 2012$ & $23: 10$ & $\mathrm{~S}$ & 79.137 & 6.1215 & & - & 23.9 & 0 & 0 & \\
\hline $18 / 07 / 2012$ & $00: 40$ & & 79.029 & 6.9985 & & & & & & \\
\hline \multirow[t]{2}{*}{$18 / 07 / 2012$} & $02: 50$ & $\mathrm{~S}$ & 79.0309 & 7.0078 & & - & 67.3 & 0 & 0 & \\
\hline & $06: 50$ & & 78.6506 & 9.4362 & & & & & & \\
\hline \multirow[t]{2}{*}{$18 / 07 / 2012$} & $16: 30$ & $\mathrm{~S}$ & 78.6352 & 9.4408 & & - & 58.2 & 0 & 0 & \\
\hline & 20:00 & & 79.0252 & 11.0469 & & & & & & \\
\hline
\end{tabular}


Table 1 continued

\begin{tabular}{|c|c|c|c|c|c|c|c|c|c|c|}
\hline Date & $\begin{array}{l}\text { Time } \\
\text { (h) }\end{array}$ & Platform & Latitude & Longitude & $\begin{array}{l}\text { Mean altitude } \\
\text { (m) }\end{array}$ & Ice & $\begin{array}{l}\text { Distance } \\
(\mathrm{km})\end{array}$ & $\begin{array}{l}\text { Litter } \\
\text { count }\end{array}$ & $\begin{array}{l}\text { Litter count } \\
\mathrm{km}^{-1}\end{array}$ & Litter type \\
\hline \multirow[t]{2}{*}{$18 / 07 / 2012$} & $21: 10$ & $\mathrm{~S}$ & 79.0301 & 11.0471 & & - & 26.6 & 0 & 0 & \\
\hline & $22: 55$ & & 78.9935 & 9.8065 & & & & & & \\
\hline \multirow[t]{2}{*}{$19 / 07 / 2012$} & $00: 30$ & $\mathrm{~S}$ & 78.9827 & 9.4924 & & - & 109.1 & 0 & 0 & \\
\hline & 07:00 & & 79.0814 & 4.3658 & & & & & & \\
\hline \multirow[t]{2}{*}{$19 / 07 / 2012$} & $10: 35$ & $\mathrm{~S}$ & 79.0803 & 4.3535 & & - & 15.9 & 0 & 0 & \\
\hline & $11: 35$ & & 78.9707 & 4.8321 & & & & & & \\
\hline \multirow[t]{2}{*}{$19 / 07 / 2012$} & $13: 50$ & $\mathrm{~S}$ & 78.8624 & 5.1513 & & - & 9.4 & 0 & 0 & \\
\hline & $14: 20$ & & 78.7840 & 5.3165 & & & & & & \\
\hline \multirow[t]{2}{*}{$19 / 07 / 2012$} & $19: 50$ & $\mathrm{~S}$ & 78.7561 & 5.3287 & & - & 17.2 & 0 & 0 & \\
\hline & $20: 50$ & & 78.6178 & 4.9871 & & & & & & \\
\hline \multirow[t]{2}{*}{ 20/07/2012 } & $21: 50$ & $\mathrm{~S}$ & 78.6170 & 5.0758 & & - & 17.6 & 0 & 0 & \\
\hline & $22: 50$ & & 78.7687 & 5.3140 & & & & & & \\
\hline \multirow[t]{2}{*}{ 21/07/2012 } & $00: 20$ & $\mathrm{~S}$ & 78.7812 & 5.3321 & & - & 16.0 & 1 & 0.06270 & Plastic waste \\
\hline & $01: 20$ & & 78.9113 & 5.0180 & & & & & & \\
\hline \multirow[t]{2}{*}{ 21/07/2012 } & $06: 10$ & $\mathrm{~S}$ & 78.9179 & 5.0058 & & - & 17.0 & 0 & 0 & \\
\hline & $07: 10$ & & 79.0048 & 4.3472 & & & & & & \\
\hline \multirow[t]{2}{*}{$22 / 07 / 2012$} & $18: 40$ & $\mathrm{~S}$ & 79.0713 & 3.3276 & & - & 9.2 & 0 & 0 & \\
\hline & $19: 10$ & & 79.1167 & 2.9626 & & & & & & \\
\hline \multirow[t]{2}{*}{ 23/07/2012 } & $07: 40$ & $\mathrm{~S}$ & 79.1354 & 2.8235 & & - & 74.3 & 0 & 0 & \\
\hline & $10: 40$ & & 79.7312 & 4.4822 & & & & & & \\
\hline \multirow[t]{2}{*}{ 23/07/2012 } & $21: 40$ & $\mathrm{~S}$ & 79.7528 & 4.4198 & & + & 23.3 & 0 & 0 & \\
\hline & $23: 10$ & & 79.8889 & 3.5201 & & & & & & \\
\hline \multirow[t]{2}{*}{$24 / 07 / 2012$} & $10: 40$ & $\mathrm{~S}$ & 79.9033 & 3.2753 & & + & 5.7 & 0 & 0 & \\
\hline & $11: 10$ & & 79.8810 & 3.4898 & & & & & & \\
\hline \multirow[t]{2}{*}{$24 / 07 / 2012$} & 20:00 & $\mathrm{S}$ & 79.8070 & 3.3816 & & + & 42.5 & 0 & 0 & \\
\hline & $22: 26$ & & 79.5993 & 5.1544 & & & & & & \\
\hline \multirow[t]{2}{*}{ 25/07/2012 } & 05:00 & $\mathrm{S}$ & 79.6047 & 5.1739 & & - & 18.1 & 0 & 0 & \\
\hline & 06:00 & & 79.7258 & 4.5767 & & & & & & \\
\hline \multirow[t]{2}{*}{$25 / 07 / 2012$} & $18: 10$ & $\mathrm{~S}$ & 79.6722 & 4.2615 & & - & 25.5 & 0 & 0 & \\
\hline & $19: 40$ & & 79.4524 & 4.6250 & & & & & & \\
\hline \multirow[t]{2}{*}{ 26/07/2012 } & $02: 10$ & $\mathrm{~S}$ & 79.5289 & 4.7346 & & - & 9.3 & 2 & 0.21570 & Plastic waste \\
\hline & $03: 10$ & & 79.6122 & 4.7616 & & & & & & \\
\hline \multirow[t]{2}{*}{ 26/07/2012 } & 09:10 & $\mathrm{S}$ & 79.6949 & 4.8133 & & + & 9.5 & 0 & 0 & \\
\hline & 09:40 & & 79.6240 & 5.0748 & & & & & & \\
\hline \multirow[t]{2}{*}{ 26/07/2012 } & $15: 50$ & $\mathrm{~S}$ & 79.4731 & 4.9845 & & - & 24.7 & 0 & 0 & \\
\hline & $17: 20$ & & 79.2856 & 4.3443 & & & & & & \\
\hline $26 / 07 / 2012$ & $22: 40$ & $\mathrm{~S}$ & 79.2850 & 4.3068 & & - & 24.7 & 0 & 0 & \\
\hline $27 / 07 / 2012$ & $00: 10$ & & 79.0793 & 4.1003 & & & & & & \\
\hline \multirow[t]{2}{*}{$27 / 07 / 2012$} & $11: 45$ & $\mathrm{~S}$ & 79.0942 & 4.5834 & & - & 15.7 & 1 & 0.06376 & Plastic waste \\
\hline & $12: 45$ & & 78.9658 & 4.8887 & & & & & & \\
\hline $27 / 07 / 2012$ & $14: 50$ & $\mathrm{~S}$ & 78.9087 & 5.0857 & & - & 505.6 & 1 & 0.00198 & Plastic waste \\
\hline $28 / 07 / 2012$ & $15: 30$ & & 74.6736 & 12.3374 & & & & & & \\
\hline $28 / 07 / 2012$ & $18: 10$ & $\mathrm{~S}$ & 74.7457 & 12.0306 & & - & 582.1 & 2 & 0.00344 & Plastic waste, \\
\hline $30 / 07 / 2012$ & 01:30 & & 70.3897 & 20.0441 & & & & & & Plastic bag \\
\hline Total ship & & & & & & & 2031.0 & 8 & 0.00394 & \\
\hline
\end{tabular}

The two lines show starting time and position and end time and position of each survey 
A total distance of $3537 \mathrm{~km}$ was surveyed by helicopter and litter observed during six of the 13 flights undertaken (46\%) (Table 1). Mean litter quantities ranged from 0 to 0.01850 items $\mathrm{km}^{-1}$. Twenty-three items of floating plastic were recorded during these flights. The quantity of floating litter recorded was not significantly correlated with flight altitude $(r=0.44, p=0.133)$ or speed $(r=-0.12$, $p=0.709)$.

Although the majority of floating litter was observed in the eastern Fram Strait west of Svalbard, six items were also recorded from the western Barents Sea (Fig. 1). Unlike the results from ship-based surveys, litter recorded during helicopter flights was not restricted to the westernmost flanks of the surveyed area.

More floating litter was recorded during helicopterbased surveys than during ship-based surveys (0.0065 and 0.0039 items $\mathrm{km}^{-1}$, respectively). If all surveys were divided into Fram Strait and Barents Sea (south of Svalbard) transects, litter densities were slightly higher in the Fram Strait $\left(0.0062\right.$ items $\left.\mathrm{km}^{-1}\right)$ than in the Barents Sea (0.0044 items $\left.\mathrm{km}^{-1}\right)$. However, while the densities obtained from helicopter-based surveys were similar in both regions (0.0066 and 0.0063 items $\mathrm{km}^{-1}$ in the Barents Sea and Fram Strait, respectively), the ship-based surveys yielded almost twice as much litter in the northern $(0.0053$ items $\mathrm{km}^{-1}$ ) compared with the southern survey area $\left(0.0028\right.$ items $\left.\mathrm{km}^{-1}\right)$. We did not run statistical tests as 39 transects were done in the Fram Strait compared with only five in the Barents Sea.

\section{Discussion}

Our results highlight the presence of floating plastic litter items in the Barents Sea and in the Arctic. However, since the distance between the objects and the ship was not estimated and as no calibration was undertaken prior to helicopter flights, we can only provide linear densities $\left(\mathrm{km}^{-1}\right)$ rather than litter densities per area $\left(\mathrm{km}^{-2}\right)$. Therefore, our data are not comparable with those from many other studies (e.g. Ryan 1988; Lecke-Mitchell and Mullin 1997; Barnes and Milner 2005; Pichel et al. 2007, 2012). Still, conversion of figures given in Ryan (2013, 2014), Ryan et al. (2014) and Miranda-Urbina et al. (2015) to items $\mathrm{km}^{-1}$ enables a comparison with our ship-based data. This suggests that floating debris in the Barents Sea/Fram Strait area (0.0039 items $\left.\mathrm{km}^{-1}\right)$ is slightly higher than that in the Antarctic $\left(0.0013\right.$ items $\left.\mathrm{km}^{-1}\right)$ and sub-Antarctic Southern Ocean (0.0015 items $\left.\mathrm{km}^{-1}\right)$, but much lower than that at lower latitudes such as the temperate Southern Ocean (0.0217 items $\left.\mathrm{km}^{-1}\right)$, South Atlantic (0.1030 items $\mathrm{km}^{-1}$ ), South Pacific (0.0768 items $\mathrm{km}^{-1}$ ), Bay of Bengal (0.2484 items $\mathrm{km}^{-1}$ ) or even the Straits of Malacca (15.9389 items $\mathrm{km}^{-1}$ ).
It could be concluded that sea ice still hinders the spread of floating litter to polar regions to some extent and/or that the distance to more populated areas currently still limits the spread of litter to polar regions.

In annual Barents Sea fisheries surveys, plastic also dominates floating litter and tends to drift along the main currents (Prokhorova 2014), with most counts located between $69^{\circ}$ and $74^{\circ} \mathrm{N}$ and $25^{\circ}$ and $45^{\circ} \mathrm{E}$ - an area influenced by the North Cape and Murman Currents. However, the area surveyed is located further to the east than ours, north of Murmansk, and cannot be compared as no reference to distance or area covered is provided. Their highest litter counts coincide with areas of intensive fishery and shipping. Indeed, Sswat et al. (2015) reported evidence of trawling activities at all stations $>300 \mathrm{~m}$ depth on the seabed northwest of Svalbard.

Our linear litter densities can also be compared with those from the seafloor of the HAUSGARTEN observatory, which is located below the parts of the present study area: analysis of images taken by a towed camera system yielded 2.24-18.47 items $\mathrm{km}^{-1}$ at $2500 \mathrm{~m}$ water depth (data from Bergmann and Klages (2012), converted to linear transect length for comparison). Surface litter quantities recorded in the HAUSGARTEN area (this study) were between 0 and 0.22 items $\mathrm{km}^{-1}$ and were thus 1-2 orders of magnitude lower compared with benthic litter. From this, it could be inferred that the seafloor may act as a sink of litter, as proposed by Woodall et al. (2014). Contrary to a common notion that most plastics are characterised by a low density and will only sink after fouling organisms and sediments have added weight, it has been estimated that $50 \%$ of the plastics from municipal waste exceed the density of sea water such that it readily sinks to the seafloor (Engler 2012), which is enhanced by strong winds and storms (Kukulka et al. 2012). However, litter quantities on the seafloor were probably also higher because the camera was towed at lower altitude $(1.5 \mathrm{~m})$ compared with the distance between helicopter- or shipbased observers and the sea surface, resulting in higher counts of (smaller-sized) litter on the seafloor.

Despite the advantage of the large geographic ranges covered, few studies rely on aircraft for the assessment of floating litter. Ryan (1988) reported mean densities of large plastic items on aerial transects 10 and $50 \mathrm{~km}$ off Cape Columbine and Cape Point of 1.64 and 19.64 items $\mathrm{km}^{-2}$, respectively, at a flight altitude of $130 \mathrm{~m}$. Lecke-Mitchell and Mullin (1997) reported densities of 1 litter item $\mathrm{km}^{-2}$ from the Gulf of Mexico (229 m altitude). Although Pichel et al. (2007) flew at lower speed $\left(100 \mathrm{~m} \mathrm{~s}^{-1}\right)$ but at a higher altitude $(300 \mathrm{~m})$, their surveys in the North Pacific yielded seemingly higher litter counts (279-875 litter items). However, strictly speaking no comparison can be made as no area estimate was provided. Pichel et al. (2012) 
reported 102 items of anthropogenic or terrestrial origin in the Gulf of Alaska, but no transect lengths were given. Sighting data from aerial surveys conducted for a variety of purposes (e.g. fishery patrols, coast guard) could be used in an 'aircraft-of-opportunity' approach to increase our knowledge on the global distribution of litter, especially in poorly known remote areas. However, standard operational protocols are needed to ensure the comparability of data. To aid comparability, future surveys should provide both linear and area density estimates or at least survey distances as 'ship/aircraft-of-opportunity' type of surveys may not always be able to do the calibrations required to derive area density estimates, whereas platform positions are often recorded by default. From this, survey distance and linear density can be calculated, which would increase our knowledge base, especially for poorly sampled regions.

Since the global plastic production grows $\sim 4 \%$ per year and demand reached 299 million $t$ in 2013 (PlasticsEurope 2015), the contamination of the ocean with litter is likely to rise (Jambeck et al. 2015). Our report highlights once again that even remote and thus presumably pristine environments such as the Arctic are not exempt from plastic pollution. Indeed, litter pollution in the Arctic is likely to increase as anthropogenic pressure will grow due to easier access to this region caused by the decreased sea ice cover. In addition, the long-term mean net volume transport in the West Spitsbergen Current, which is derived from the North Atlantic, was estimated at 6.6 Sverdrup (Beszczynska-Möller et al. 2012). This implies that there will be a constant supply of litter transported to the north with water masses of Atlantic origin.

This notion is corroborated by models projecting the formation of a sixth garbage patch in the Barents Sea region (van Sebille et al. 2012), which is probably due to highly populated coasts of the North Atlantic and may leak to the north. Assuming that significant litter inputs began in the 1970s and that the formation of this garbage patch is projected for 50 years, it seems reasonable to assume that there are already significant quantities in this region to be detected. Unfortunately, we cannot compare our data with these projections due to low spatial model resolution and because no true litter density units are provided.

One of the threats posed by floating litter is the risk of alien invasion through long-distance transport and ingestion. Indeed, plastic debris from Svalbard harboured xenobiota such as the barnacle Semibalanus balanoides and the bryozoan Membranipora membranacea (Barnes and Milner 2005). The risk of alien invasion in the Arctic may be ever higher when sea ice shrinkage reduces an effective barrier to both litter and exotics (Barnes 2002). In terms of the risk of ingestion, $8 \%$ of Greenland sharks (Somniosus microcephalus) caught off South Greenland and $3 \%$ of conspecifics from Kongsfjord, close to our study area, ingested litter as did $88 \%$ northern fulmars (Fulmarus glacialis) from the nearby Isfjord (Leclerc et al. 2012; Nielsen et al. 2014; Trevail et al. 2015).

The global increase in marine litter, even at remote locations such as the poles, highlights the fact that the implementation of the current legislation does not suffice to tackle the problem of poor practices of solid waste management. Unless effective action is taken, it will only continue to worsen in years to come (Jambeck et al. 2015).

Acknowledgments We thank the officers and crew of $R V$ Polarstern, pilots of HeliService International $\mathrm{GmbH}$ and the observers Q. Goffette and D. Sevrin (PolE). MB was funded by the Helmholtz Alliance ROBEX (Robotic Exploration of Extreme Environments), and this study contributes to the tasks of the Helmholtz-funded programme FRAM (Frontiers in Arctic Marine Research). M. Thiel, P. Ryan and J.H. Churnside improved earlier versions of the MS. This publication is Eprint ID 31691 of the Alfred-Wegener-Institut, Helmholtz-Zentrum für Polar- und Meeresforschung.

Open Access This article is distributed under the terms of the Creative Commons Attribution 4.0 International License (http://creati vecommons.org/licenses/by/4.0/), which permits unrestricted use, distribution, and reproduction in any medium, provided you give appropriate credit to the original author(s) and the source, provide a link to the Creative Commons license, and indicate if changes were made.

\section{References}

Andrady AL (2015) Persistence of plastic litter in the oceans. In: Bergmann M, Gutow L, Klages M (eds) Marine anthropogenic litter. Springer, Berlin, pp 57-74. doi:10.1007/978-3-319-1651033

Barnes DKA (2002) Biodiversity: invasions by marine life on plastic debris. Nature 416:808-809. doi:10.1038/416808a

Barnes DKA, Milner P (2005) Drifting plastic and its consequences for sessile organism dispersal in the Atlantic Ocean. Mar Biol 146:815-825. doi:10.1007/s00227-004-1474-8

Bergmann M, Klages M (2012) Increase of litter at the Arctic deepsea observatory HAUSGARTEN. Mar Pollut Bull 64:2734-2741. doi:10.1016/j.marpolbul.2012.09.018

Beszczynska-Möller A, Fahrbach E, Schauer U, Hansen E (2012) Variability in Atlantic water temperature and transport at the entrance to the Arctic Ocean, 1997-2010. ICES J Mar Sci 69:852-863. doi:10.1093/icesjms/fss056

Cózar A, Echevarría F, González-Gordillo JI, Irigoien X, Úbeda B, Hernández-León S, Palma ÁT, Navarro S, García-de-Lomas J, Ruiz A, Fernández-de-Puelles ML, Duarte CM (2014) Plastic debris in the open ocean. Proc Natl Acad Sci USA 111:10239-10244. doi:10.1073/pnas.1314705111

Engler RE (2012) The complex interaction between marine debris and toxic chemicals in the ocean. Environ Sci Technol 46:12302-12315. doi:10.1021/es3027105

Eriksen M, Lebreton LCM, Carson HS, Thiel M, Moore CJ, Borerro JC, Galgani F, Ryan PG, Reisser J (2014) Plastic pollution in the world's oceans: more than 5 trillion plastic pieces weighing over 250,000 tons afloat at sea. PLoS One 9:e111913. doi:10.1371/ journal.pone.0111913

Galgani F, Hanke G, Maes T (2015) Global distribution, composition and abundance of marine litter. In: Bergmann M, Gutow L, Klages M (eds) Marine anthropogenic litter. Springer, Berlin, pp 29-56. doi:10.1007/978-3-319-16510-3_2 
Jambeck JR, Geyer R, Wilcox C, Siegler TR, Perryman M, Andrady A, Narayan R, Law KL (2015) Plastic waste inputs from land into the ocean. Science 347:768-771. doi:10.1126/science.1260352

Joiris CR (2000) Summer at-sea distribution of seabirds and marine mammals in polar ecosystems: a comparison between the European Arctic seas and the Weddell Sea, Antarctica. J Mar Syst 27:267-276. doi:10.1016/s0924-7963(00)00072-5

Kiessling T, Gutow L, Thiel M (2015) Marine litter as a habitat and dispersal vector. In: Bergmann M, Gutow L, Klages M (eds) Marine anthropogenic litter. Springer, Berlin, pp 141-181. doi:10.1007/978-3-319-16510-3_6

Kühn S, Bravo Rebolledo EL, van Franeker JA (2015) Deleterious effects of litter on marine life. In: Bergmann M, Gutow L, Klages M (eds) Marine anthropogenic litter. Springer, Berlin, pp 75-116. doi:10.1007/978-3-319-16510-3_4

Kukulka T, Proskurowski G, Morét-Ferguson S, Meyer DW, Law KL (2012) The effect of wind mixing on the vertical distribution of buoyant plastic debris. Geophys Res Lett 39:L07601. doi:10. 1029/2012g1051116

Lecke-Mitchell KM, Mullin K (1997) Floating marine debris in the US Gulf of Mexico. Mar Pollut Bull 34:702-705. doi:10.1016/ S0025-326X(97)00027-1

Leclerc L-M, Lydersen C, Haug T, Bachmann L, Fisk A, Kovacs K (2012) A missing piece in the Arctic food web puzzle? Stomach contents of Greenland sharks sampled in Svalbard, Norway. Polar Biol 35:1197-1208. doi:10.1007/s00300-012-1166-7

Miranda-Urbina D, Thiel M, Luna-Jorquera G (2015) Litter and seabirds found across a longitudinal gradient in the South Pacific Ocean. Mar Pollut Bull 95:235-244. doi:10.1016/j.marpolbul.2015.05.021

Nielsen J, Hedeholm RB, Simon M, Steffensen JF (2014) Distribution and feeding ecology of the Greenland shark (Somniosus microcephalus) in Greenland waters. Polar Biol 37:37-46. doi:10.1007/s00300-013-1408-3

Pichel WG, Churnside JH, Veenstra TS, Foley DG, Friedman KS, Brainard RE, Nicoll JB, Zheng Q, Clemente-Colon P (2007) Marine debris collects within the North Pacific subtropical convergence zone. Mar Pollut Bull 54:1207-1211. doi:10.1016/j. marpolbul.2007.04.010

Pichel WG, Veenstra TS, Churnside JH, Arabini E, Friedman KS, Foley DG, Brainard RE, Kiefer D, Ogle S, Clemente-Colón P, Li X (2012) GhostNet marine debris survey in the Gulf of AlaskaSatellite guidance and aircraft observations. Mar Pollut Bull 65:28-41. doi:10.1016/j.marpolbul.2011.10.009
PlasticsEurope (2015) Plastics-the facts 2014/2015, Brussels. http:// www.plasticseurope.org/Document/plastics-the-facts-20142015. aspx?FolID $=2$

Prokhorova T (2014) Pollution. Anthropogenic matter. In: Eriksen E (ed) Survey report from the joint Norwegian/Russian ecosystem survey in the Barents Sea and adjacent waters, August-October 2014, pp 153. http://www.imr.no/filarkiv/2015/04/imr-pinro_12015_til_web.pdf/nb-no

Ryan PG (1988) The characteristics and distribution of plastic particles at the sea-surface off the southwestern Cape Province, South Africa. Mar Environ Res 25:249-273. doi:10.1016/01411136(88)90015-3

Ryan PG (2013) A simple technique for counting marine debris at sea reveals steep litter gradients between the Straits of Malacca and the Bay of Bengal. Mar Pollut Bull 69:128-136. doi:10.1016/j. marpolbul.2013.01.016

Ryan PG (2014) Litter survey detects the South Atlantic 'garbage patch'. Mar Pollut Bull 79:220-224. doi:10.1016/j.marpolbul. 2013.12.010

Ryan PG (2015) A brief history of marine litter research. In: Bergmann M, Gutow L, Klages M (eds) Marine anthropogenic litter. Springer, Berlin, pp 1-25. doi:10.1007/978-3-319-165103 1

Ryan PG, Musker S, Rink A (2014) Low densities of drifting litter in the African sector of the Southern Ocean. Mar Pollut Bull 89:16-19. doi:10.1016/j.marpolbul.2014.10.043

Sswat M, Gulliksen B, Menn I, Sweetman AK, Piepenburg D (2015) Distribution and composition of the epibenthic megafauna north of Svalbard (Arctic). Polar Biol 38:861-877. doi:10.1007/ s00300-015-1645-8

Trevail AM, Gabrielsen GW, Kühn S, Van Franeker JA (2015) Elevated levels of ingested plastic in a high Arctic seabird, the northern fulmar (Fulmarus glacialis). Polar Biol 38:975-981. doi:10.1007/s00300-015-1657-4

Van Sebille E, England MH, Froyland G (2012) Origin, dynamics and evolution of ocean garbage patches from observed surface drifters. Environ Res Lett 7:044040. doi:10.1088/1748-9326/7/4/ 044040

Woodall LC, Sanchez-Vidal A, Canals M, Paterson GLJ, Coppock R, Sleight V, Calafat AM, Rogers AD, Narayanaswamy BE, Thompson RC (2014) The deep sea is a major sink for microplastic debris. R Soc Open Sci 1:140317. doi:10.1098/ rsos. 140317 